\title{
Risk Modelling of Organic Pollution in Lake Sediments
}

\author{
Irina Schneider*, Yana Topalova \\ Department of General and Applied Hydrobiology, Faculty of Biology, Sofia University "St. Kliment Ohridski”, \\ Sofia, Bulgaria \\ Email: *i.schneider@abv.bg
}

Received 4 February 2016; accepted 28 March 2016; published 31 March 2016

Copyright (C) 2016 by authors and Scientific Research Publishing Inc.

This work is licensed under the Creative Commons Attribution International License (CC BY). http://creativecommons.org/licenses/by/4.0/

(c) (i) Open Access

\begin{abstract}
A risk situation of organic pollutants accumulation in the sediments of the dams from Cascade "Middle Iskar" (NW Bulgaria) is simulated in the present study. The aim is risk modelling of organic pollution in lake sediments and on base of the investigated key chemical and enzymological parameters to risk assessment. A model process in lab scale with addition of whey as a source of organic pollutants was simulated. Two situations near to real conditions were studied: 1) at a decreased concentration of organic pollutants (chemical oxygen demand was $0.265 \mathrm{gO}_{2} \cdot \mathrm{kg}^{-1}$ ) in the case of discharge of sediments downstream of the river (control situation); 2) at an accumulation of organic pollutants (chemical oxygen demand was $1.463 \mathrm{gO}_{2} \cdot \mathrm{kg}^{-1}$ ) in the sediments (risk event). The dynamics of chemical oxygen demand (COD), concentration of proteins and lactose as well as of the key enzymological indicators (phosphatase activity index-PAI, anaerobic dehydrogenase activity, protease and ß-galactosidase activities) were investigated. The data from Risk Assessment showed that there is a hazard from higher protein concentration at the end of the process in comparison with the control situation. The risk about COD and lactose concentration during the risk modelling was acceptable. The obtained results showed that the PAI can be used as an indicator for early warning of the organic pollution with protein nature.
\end{abstract}

\section{Keywords}

Biodegradable Organics, Enzyme Activity, Hydroelectric Power Plant, Iskar River, Self-Purification

\section{Introduction}

The exploration of renewable energy sources and in particular the exploitation of Hydroelectric Power Plants

${ }^{*}$ Corresponding author. 
(HEPPs) outlines new environmental risks in Water Management. An example for that in Bulgaria is the Cascade "Middle Iskar" located in highly urbanized areas (NW Bulgaria). A long-term monitoring program (from 2006 to 2015) has been applied for assessment of water quality, sediment status and self-purification potential of river and dam hydroecosystems in region of the Cascade. One of the main environmental problems, identified from the monitoring data analysis, was the accumulation of biodegradable organics (mainly proteins) in sediments in the dams to exploited HEPPs [1]. Main point source pollution in region was: sewage of Svoge Town without wastewater treatment plant (WWTP), chocolate factory of Kraft Foods Bulgaria in Svoge Town, small dairies without local WWTP nearby the middle part of Iskar River, sewage treatment plant "Kubratovo", etc. [1] [2]. Non-point source pollution in region was: villages without sewage and without municipal WWTP draining into a river, polluted runoff from agricultural areas draining into a river, as well as an illegal dump without insulation in area of Lakatnik Village [2]. Two main sources of pollution are untreated domestic and milk processing wastewater. The main characteristics of untreated domestic wastewater are: chemical oxygen demand (COD) around $500 \mathrm{mgO}_{2} / \mathrm{l}$, total nitrogen around $40 \mathrm{mg} / \mathrm{l}$ and total phosphorous around $10 \mathrm{mg} / \mathrm{l}$ [3]. The food processing wastewaters are characterized with high biodegradable organics concentration and with high nutrient concentrations (as nitrogen and phosphorous). For example, in dairies without local WWTP COD varied between 785 and $7619 \mathrm{mgO}_{2} / \mathrm{l}$ in wastewater, the total nitrogen could reach to $140 \mathrm{mg} / \mathrm{l}$, and the total phosphorous ranged from 29 to $181 \mathrm{mg} / \mathrm{l}$ [4]. All of above mentioned pollutants are concentrated in the dams built in the river and there they are accumulated in sediments as a result from natural processes of sedimentation. The absence of environmental legislation about maximal emission concentrations of the pollutants in sediments complicates significantly Risk Management.

The Risk Management is an integral part of Environmental Management Systems and it involves “considering each identified hazard in turn, considering what options are available to reduce the likelihood of the hazard occurring and to respond if it does occur, and evaluating each possible action in terms of its costs and benefits” [5]. Environmental Management Systems are a set of practices directed to reduce environmental impacts in parallel with increase operating efficiency of enterprises or local and national agencies. Risk Management Systems are a set of processes and practices directed to prediction of potential environmental risks, risk prevention and reduction of environmental impact [5] [6]. Risk Modelling is a tool of Risk Management and it is frequently applied approach in Water Management [6]. The Risk Assessment and Risk Treatment are the basic elements of Risk Management. The relationship between these basic elements and Risk Modelling is presented on Figure 1. Monitoring; determination of critical control points in time, in place and process; feedback from taken actions are required for adequate risk management. The main activities for each of the three obligatory steps of the Risk Analysis (including Risk identification, Risk analysis and Risk evaluation) are shown on Figure 1. The Risk Treatment according to ISO31000:2009 involves selecting one or more options for modifying risk, and implementing these options, including risk accept, risk transfer, risk mitigate or risk avoid. Nowadays, more and more efforts are directed to risk prevention. That included development of: systems for early warning of specific risk events; algorithms for decision making for specific environmental problems; supply of alternative solutions, and etc.

There are two main opportunities for application of the risk modelling as a tool of risk management (Figure 1). First: risk assessment for each identified hazard and evaluation of the risk acceptability. Second: if there is some unacceptable hazard after risk assessment, a modelling and assessment of alternative decisions should be undertaken. An example for risk assessment modelling is the model study for effect of mercury on the structural and functional characteristics of biofilm and on the rate of biotransformation processes in lake sediments [7]. Other studies were related to development of risk assessment scenario for an acute environmental problem such as the accumulation of heavy metals in sediments as a consequence of old industrial pollutions [1]. A part of scientific studies is directed to development of algorithms for a specific environmental problem solving in lab scale [8]. A major part of scientific efforts was directed to development, calibration and verification of mathematical models for prediction of water quality and sediment status during risk situations [6] [9] [10]. The most examples for application of risk modelling were related to development of risk management scenario for hazardous pollutants [1] [6] [11] [12]. Scarce information about risk assessment for biodegradable organic pollutants was ascertained [13]. The aim of this study is risk modelling of organic pollution in lake sediments and on base of the investigated key chemical and enzymological parameters to accomplish a risk assessment. 


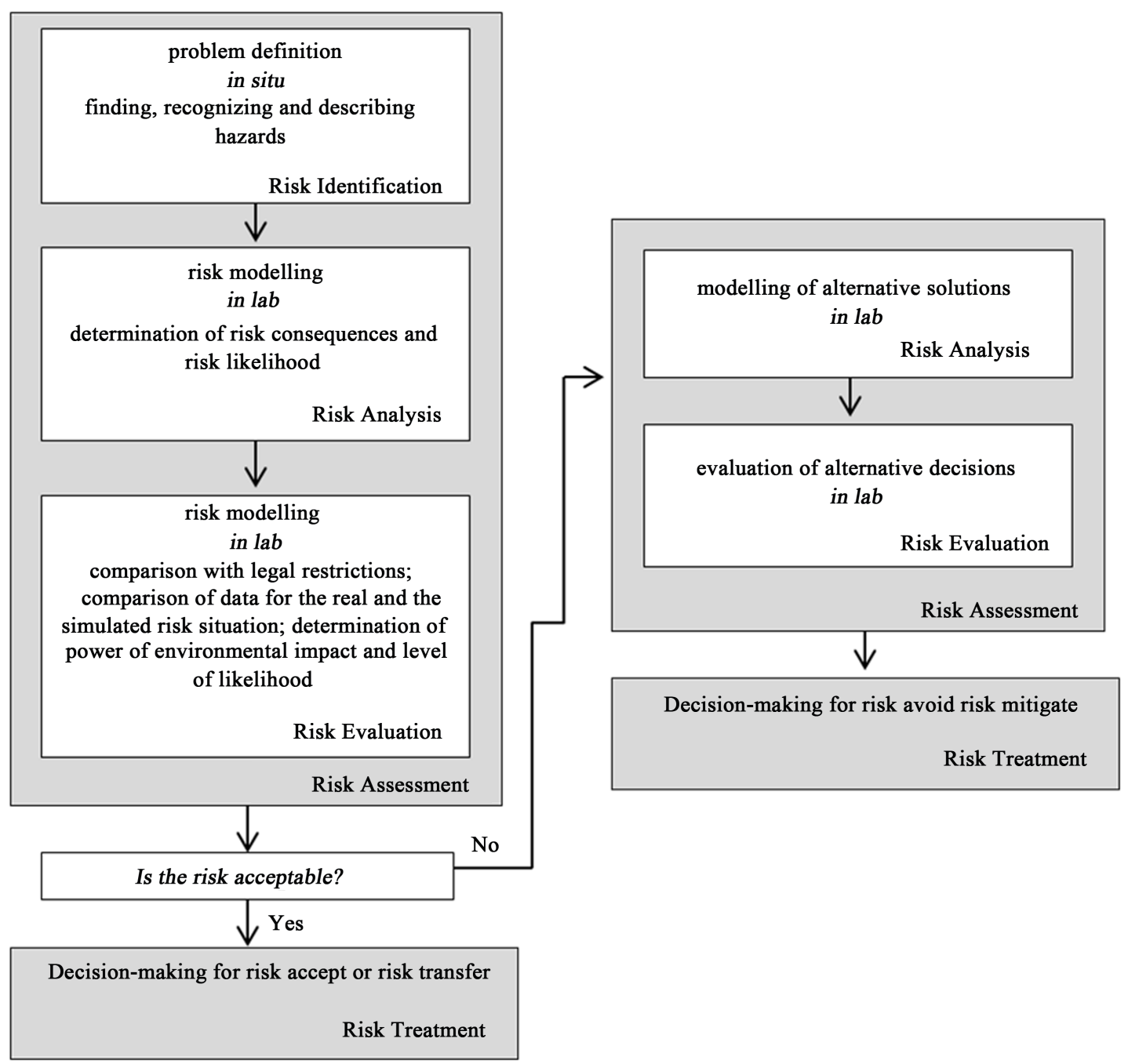

Figure 1. Risk modelling as a tool of risk management.

\section{Materials and Methods}

\subsection{Experimental Design}

The experimental design of this study is shown on Figure 2. It was based on Environmental Management Systems and Risk Management. The Risk Identification was based on in situ data obtained for the first nine years from the Monitoring program. The accidental hazard with organic pollution (COD was $0.85 \mathrm{~g} \mathrm{O}_{2} \cdot \mathrm{kg}^{-1}$ ) in lake sediments was ascertained in comparison with background data (COD varied between 0.20 and $0.27 \mathrm{~g} \mathrm{O}_{2} \cdot \mathrm{kg}^{-1}$ ). That led to simulation of this risk event in lab scale. Two situations near to the real conditions were studied: 1) at a decreased concentration of organic pollutants (COD was $0.265 \mathrm{~g} \mathrm{O}_{2} \cdot \mathrm{kg}^{-1}$ ) in the case of discharge of sediments downstream of the river (control situation); 2) at an accumulation of organic pollutants (COD was $1.463 \mathrm{~g}$ $\mathrm{O}_{2} \cdot \mathrm{kg}^{-1}$ ) in the sediments by addition of dry whey in concentration $2 \mathrm{~g} \cdot \mathrm{kg}^{-1}$ (risk event). The whey as a model pollutant was used because it contained organics such as proteins and lactose. The duration of the simulated process was 190 hours. Anaerobic conditions were created spontaneously during this period (by oxygen depletion during biochemical processes) and the rate of biodegradation processes was decreased significantly at the end of the process. After this period the pollutants concentration remains constant without significant changes. The conditions in the model reactors maximally corresponded to the real conditions in the storage reservoir. The investigated sediments and water from the reservoir to the HEPP "Lakatnik" were taken during September 2011. The volume of the sediments to the volume of water was 1:1. The model process was accomplished in sealed 


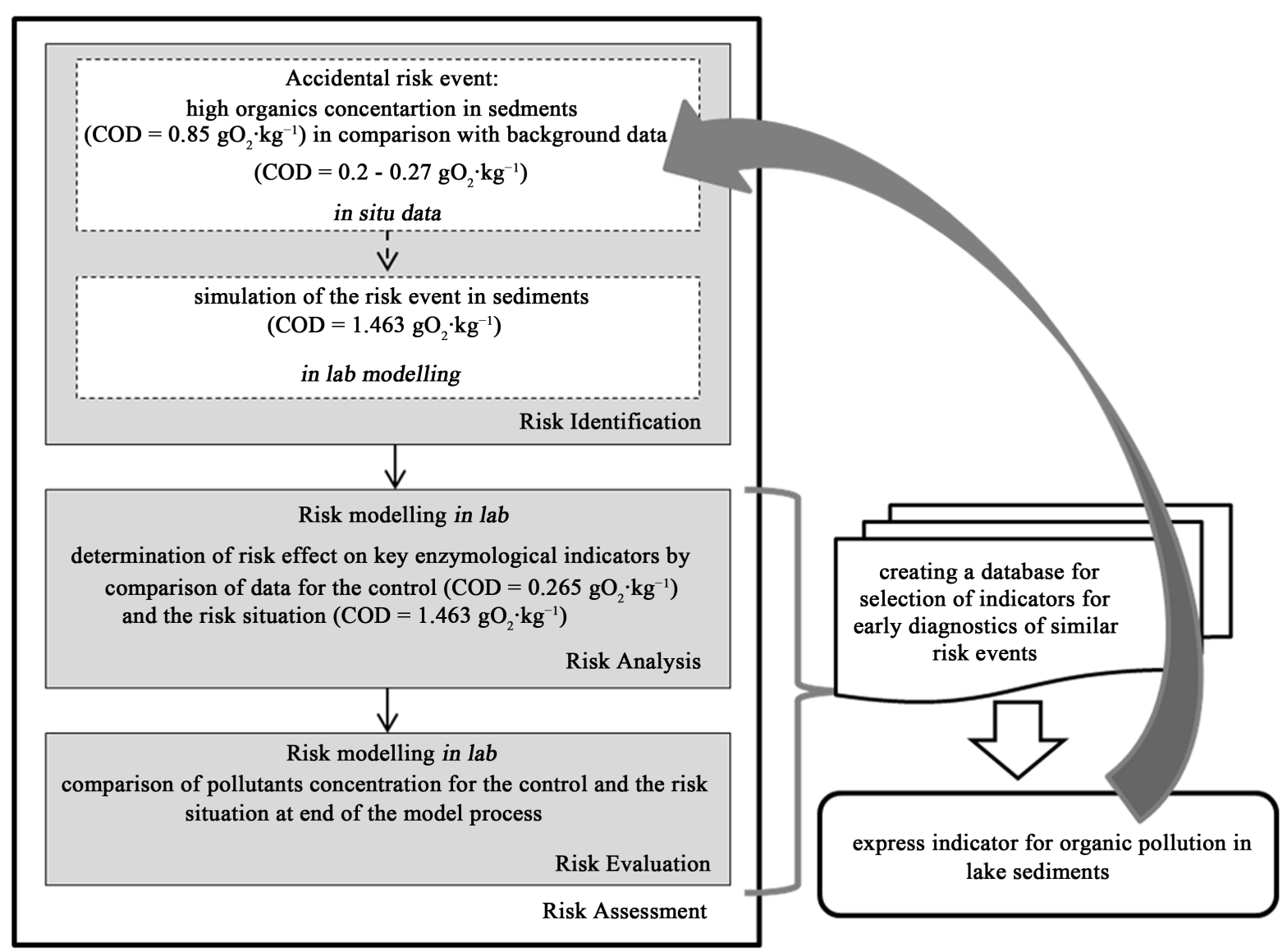

Figure 2. Experimental design of the study.

airtight conical tubes with a total volume $50 \mathrm{ml}$. Twenty one reactors were used for every variant with three repetitions for every hour of sampling. The standard deviations (SD) of the chemical and the enzymological parameters which are shown on the figures were calculated from these three independent repetitions. The reactors were placed in the thermostat in dark conditions for the photosynthesis inhibition because in the real situation on the bottom of lake this process isn't accomplished. The reactors were incubated at a temperature $19^{\circ} \mathrm{C} \pm 2^{\circ} \mathrm{C}$.

The Risk Analysis was based on the determination of the risk effect on the enzyme activities because they are more sensitive indicator in comparison to bioindicators on organism level and information is receives for some hours. The activities of anaerobic dehydrogenase (anDHA), protease (PRT), ß-galactosidase (GAL) as well as of phosphatase activity index (PAI) were studied. These enzyme activities are directly related to the organic matter biotransformation under aerobic and anaerobic conditions. The risk effect $\left(\mathrm{E}_{\mathrm{R}}\right)$ was determined as a ratio of the enzyme activity for the risk situation $\left(\mathrm{EA}_{\mathrm{Risk}}\right)$ to the enzyme activity for the control $\left(\mathrm{EA}_{\mathrm{Control}}\right)$. Equation (1) was used for calculation of the risk effect.

$$
\mathrm{E}_{\mathrm{R}}=\frac{\mathrm{EA}_{\text {Risk }}}{\mathrm{EA}_{\text {Control }}}
$$

IF $E_{R}$ was 1.0, the risk event had no effect on the enzyme activity. IF $E_{R}$ was below 1.0, the risk event had negative (inhibiting) effect on the enzyme activity. IF $E_{R}$ was above 1.0, the risk event had positive (stimulating) effect on the enzyme activity.

The Risk Evaluation was based on comparison of pollutants concentration for the control and for the risk situation at the end of the process because of absence of environmental legislation about maximal emission concentrations of pollutants in sediments. The organic pollutants (measured as COD), concentrations of proteins and lactose were investigated.

The systems for early warning play an important role in the risk management. Therefore indicators for early 
warning for similar hazards were explored. The obtained data from risk modelling were used. Linear Regression Analysis for determination of the Pearson's correlation coefficient (r) between chemical and enzymological data was used. A sign preceding the coefficient of correlation (+ or - ) indicates the direction of correlation. The significance of the correlation is expressed by $\mathrm{P}$ value that is below 0.05 in analysis.

\subsection{Analytical Methods}

The pretreatment of the samples for quantitative determination of COD, proteins and lactose included centrifugation (1000 rpm· $\mathrm{min}^{-1}$ for $15 \mathrm{~min}$.) in order to remove the sample turbidity. The supernatant was analyzed spectrophotometrically. The COD was analyzed according to a standard procedure [14]. The protein concentration was determined by Microbiuret method [15] and the lactose concentration according to Miller [16].

The treatment of the samples for determination of the enzyme activities included ultra sonic disintegration of samples ( $3 \times 10 \mathrm{sec}$. with frequency $22 \mathrm{kHz}$ and vibration amplitude $8 \mu \mathrm{m})$ with UD-20 automatic (Techpan) for obtaining of a homogenous microbial suspension. The phosphatase activity index (PAI) was an average value from the activities of acid, neutral and alkaline phosphatases which were analyzed according to Matavulj et al. [17]. The protease activity was determined using a method of Ladd and Butler [18]. The anaerobic dehydrogenase activity was measured by method with 2-(p-iodophenyl)-3-(p-nitrophenyl)-5-phenyl tetrazolium chloride (INT) [19]. The ß-galactosidase activity was investigated according to Miller [20]. The data for the enzyme activities were presented for unit protein [15].

\section{Results and Discussion}

Two events during risk modelling were studied. First of them, with initial COD equals $0.265 \mathrm{~g} \mathrm{O}_{2} \cdot \mathrm{kg}^{-1}$, simulated the situation with low organics concentration in sediments. In most cases, this situation was ascertained from in situ data. It was marked as a control in comparison with the second, which was marked as risk event. In the second situation, the initial COD was $1.463 \mathrm{~g} \mathrm{O}_{2} \cdot \mathrm{kg}^{-1}$ and the risk event of high concentration of organic pollutants in lake sediments was simulated.

\subsection{Dynamics of Enzymological Indicators and Pollutants Concentration during Risk Modelling}

The model biodegradation process was biphasic as it is seen from the pollutants dynamics (Figures 3-5). The early phase was registered to $46^{\text {th }}$ hour and it was characterized with utilization of easily biodegradable pollutant, the lactose (Figure 5). The late phase was registered between $46^{\text {th }}$ and $190^{\text {th }}$ hour. It was characterized with a decrease of the organics (measured as COD) and with protein biodegradation (Figure 3 and Figure 4). The biphasic character of the process was more clearly expressed for the risk event because the pollutants concentration increased 5.5 fold for COD (Figure 3(b)), 1.5 fold for the proteins (Figure 4(b)) and 9 fold for the lactose (Figure 5(b)).

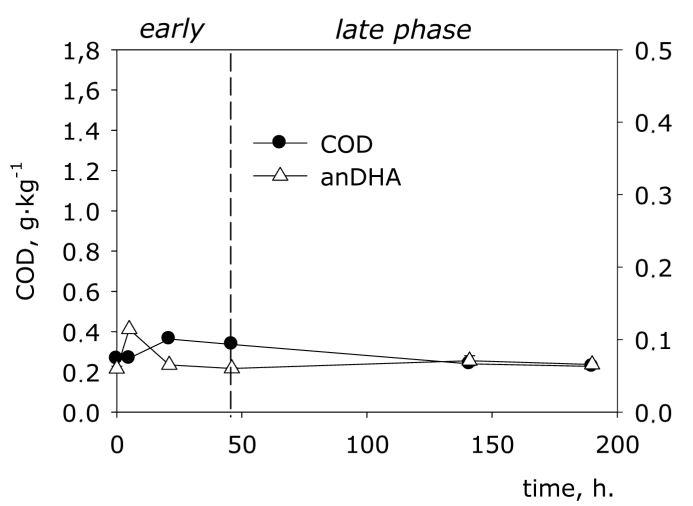

(a)

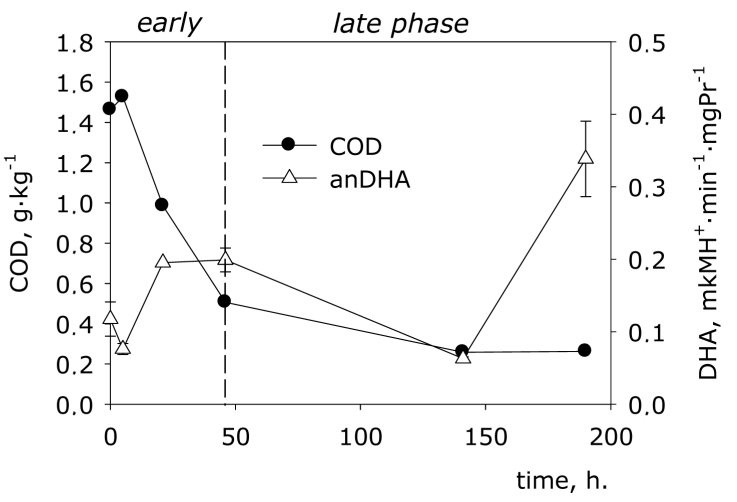

(b)

Figure 3. Dynamics of the organics (measured as COD) and of the anaerobic dehydrogenase activity (anDHA) at: (a) the control situation and (b) the risk event (mean $\pm \mathrm{SD}, \mathrm{n}=3$ ). 


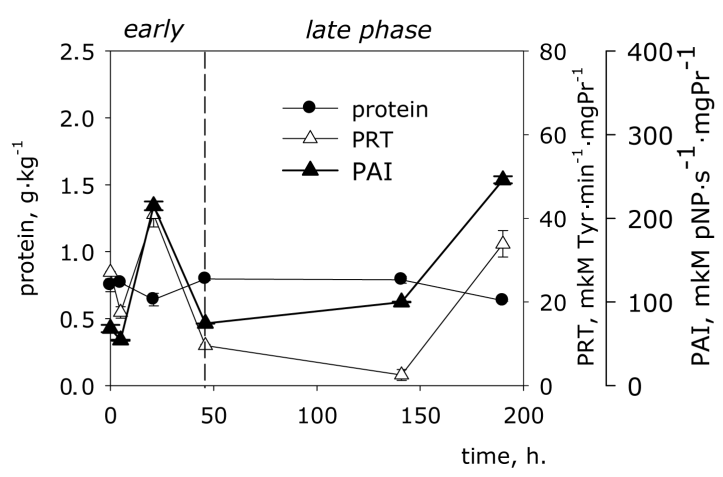

(a)

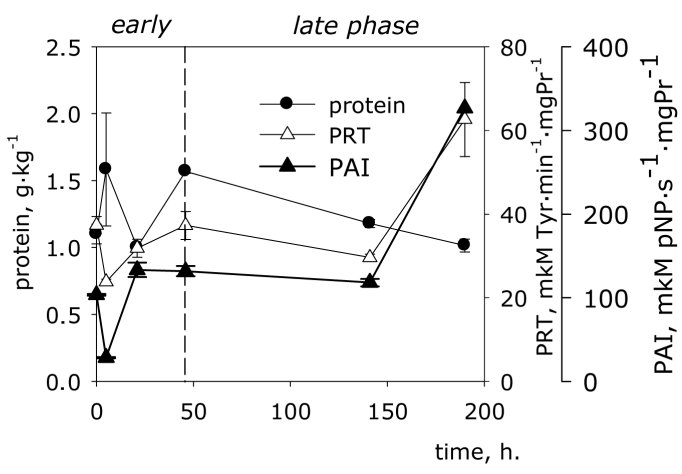

(b)

Figure 4. Dynamics of the protein concentration, the protease activity (PRT) and the phosphatase activity index (PAI) at: a) the control situation and $b$ ) the risk event (mean $\pm S D, n=3$ ).

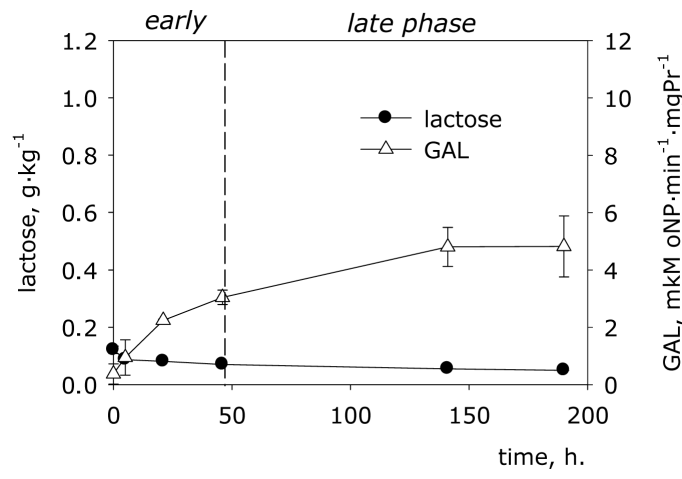

(a)

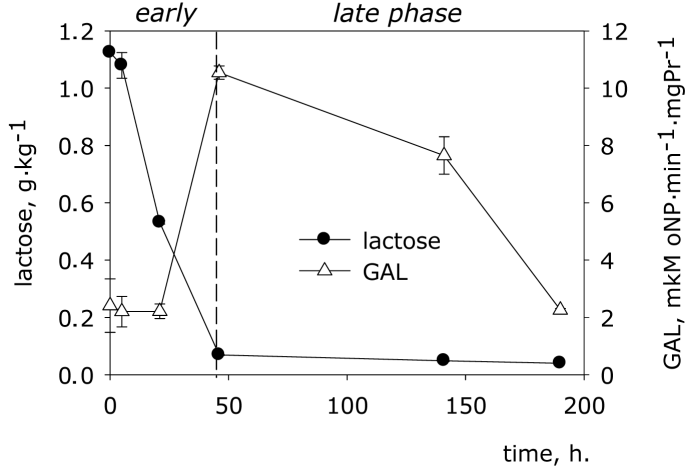

(b)

Figure 5. Dynamics of the lactose concentration and of the ß-galactosidase activity (GAL) at: (a) the control situation and (b) the risk event (mean $\pm \mathrm{SD}, \mathrm{n}=3$ ).

The dynamics of COD and the anaerobic dehydrogenase activity (anDHA) for both situations is presented on Figure 3. The followed tendencies were ascertained for the control situation (Figure 3(a)): 1) The two parameters varied in close values. At the start-up and at the end of the process COD varied between 0.265 and 0.227 $\mathrm{gO}_{2} \cdot \mathrm{kg}^{-1}$ and anDHA varied between 0.05 and $0.1 \mu \mathrm{MH}^{+} \cdot \mathrm{min}^{-1} \cdot \mathrm{mgPr}^{-1}$; 2) The peak value of anDHA was ascertained at $5^{\text {th }}$ hour which was related to low decrease of the organics. The followed tendencies for the risk event were ascertained (Figure 3(b)): 1) COD and anDHA varied significantly which indicated for faster and more dynamic processes of organic pollutants biotransformation. The COD value from 1.463 decreased to 0.262 $\mathrm{gO}_{2} \cdot \mathrm{kg}^{-1}$ at the end of the process and anDHA varied between 0.12 and $0.34 \mu \mathrm{MH}^{+} \cdot \mathrm{min}^{-1} \cdot \mathrm{mgPr}^{-1}$; 2) The first peak of anDHA $\left(0.20 \mu \mathrm{MH}^{+} \cdot \mathrm{min}^{-1} \cdot \mathrm{mgrr}^{-1}\right)$ was registered at the end of the early phase ( $46^{\text {th }}$ hour). It was related to decrease of COD from 1.46 to $0.51 \mathrm{~g} \mathrm{O}_{2} \cdot \mathrm{kg}^{-1}$. The second peak of anDHA $\left(0.34 \mu \mathrm{MH}^{+} \cdot \mathrm{min}^{-1} \cdot \mathrm{mgPr}^{-1}\right)$ was registered at the end of the late phase and it was related to decrease of COD to $0.26 \mathrm{~g} \mathrm{O}_{2} \cdot \mathrm{kg}^{-1}$.

The dynamics of protein concentration was compared with the dynamics of the phosphatase activity index (PAI) and of the protease activity (Figure 4). The peak for these two activities for the control situation was ascertained at $21^{\text {th }}$ hour. It was related to decrease of the protein concentration. An increase of proteins concentration and their retention in the system was registered at beginning of the late phase. This was likely due to availability of dead organisms and of cell lysis, which led to increase of the values of this pollutant. The second peak of the enzyme activities was registered at $190^{\text {th }}$ hour and it was related to decrease of protein concentrations, too. As a whole, the protein concentrations during the process varied in close values (between 0.64 and $0.80 \mathrm{~g} \cdot \mathrm{kg}^{-1}$ ). Unlike them, however, the enzyme activities varied significantly (between 54 and $246 \mu \mathrm{MpNP} \cdot \mathrm{s}^{-1} \cdot \mathrm{mgPr}^{-1}$ for the PAI, and between 3 and $41 \mu \mathrm{MTyr} \cdot \mathrm{min}^{-1} \cdot \mathrm{mgPr}^{-1}$ for the protease activity). The linear correlation between both enzyme activities and protein concentration for the control situation was inversely proportional (data not shown). The correlation coefficients were high ( -0.91 for the protease activity and -0.93 for the PAI). That led 
to conclusion that the biodegradable organic pollutants in the sediments were mainly with protein nature. The presence of milk proteins (caseins) which contained phosphorus could be the reason. Their sources of pollution could be the wastewater discharges from small and medium dairies.

The initial increase of the PAI and the PRT for the risk event was ascertained at $21^{\text {th }}$ hour of the process. That matched with the decrease of protein concentration from 1.6 to $1.0 \mathrm{~g} \cdot \mathrm{kg}^{-1}$. An increase of protein concentrations was registered at the end of the early phase $\left(46^{\text {th }}\right.$ hour). The communities restructuring and cell lysis with additionally release of proteins were the probable reasons. That led to retention of the values of the PAI and to increase of the PRT. Probably, the proteins which not contained phosphorous were increased because they not participate in the activation of the PAI. The second peak of the PAI and the PRT was ascertained at the end of the process $\left(190^{\text {th }}\right.$ hour $)$ and it was related to decrease of protein concentration. In comparison with the control, dynamic changes of protein concentrations (between 1.0 and $1.6 \mathrm{~g} \cdot \mathrm{kg}^{-1}$ ) were registered for the risk situation which led to significant variations of the enzyme activities (between 28 and $582 \mu \mathrm{MpNP} \cdot \mathrm{s}^{-1} \cdot \mathrm{mgPr}^{-1}$ for the PAI and between 19 and $63 \mu \mathrm{MTyr} \cdot \mathrm{min}^{-1} \cdot \mathrm{mgPr}^{-1}$ for the PRT). The microbial communities during the risk event answered on biochemical level with increase of the enzyme activities. That led to accomplishment of intensive processes of protein biotransformation. The linear correlation between protein concentration and enzyme activities was inversely proportional but in the risk event were registered lower correlation coefficients $(-0.49$ for the PRT and -0.51 for the PAI). The explanation of these results probably could be look in type of the pollutants. Protein pollutants were observed in the control situation while a bi-substrate mixture (contained protein and carbohydrate components) was investigated in the risk event. The availability of lactose as a rapidly utilized substrate inhibits synthesis and activation of proteolityc enzymes. That led to changes of the biodegradation rate and to slower response of the autochthonic community to protein utilization in the risk situation.

The dynamics of the lactose concentration and the ß-galactosidase activity (GAL) was compared for both situations (Figure 5). The lactose concentration for the control situation was very low and almost did not changed (varied between 0.12 and $0.05 \mathrm{~g} \cdot \mathrm{kg}^{-1}$ ) during the process. That is an indicator that the carbohydrate components (from uncontrollable discharge of wastewater) were hydrolyzed at the source of pollution and did not accumulated in the sediments. A gradual increase of the GAL at the early phase was registered and the peak (4.8 $\left.\mu \mathrm{MoNP} \cdot \mathrm{min}^{-1} \cdot \mathrm{mgPr}^{-1}\right)$ was ascertained at the end of the process. The higher lactose concentration $\left(1.12 \mathrm{~g} \cdot \mathrm{kg}^{-1}\right)$ for the risk event was a result of the added whey. The sharp increase of the GAL $\left(10.54 \mu \mathrm{MoNP} \cdot \mathrm{min}^{-1} \cdot \mathrm{mgPr}^{-1}\right)$ was registered at the end of the early phase $\left(46^{\text {th }}\right.$ hour), which was related to a sharp decrease of the lactose (to $\left.0.07 \mathrm{~g} \cdot \mathrm{kg}^{-1}\right)$. The GAL at the late phase decrease gradually as a result of the reduced concentration of the inductor.

The values among the three repetitions for all investigated parameters fluctuated in close range (Figures 3-5). Single exceptions are registered and they are related with availability of sediments particles that probably hinder the full homogenization of the composition of the sample. The obtained results about the dynamics of the parameters during modelling highlight two important trends. Firstly, the biochemical response of the autochthonic community in risk event of organic pollution in sediments was related to increase of the activity of the key enzymes which are responsible for the initial organics biodegradation. Second, the biotransformation processes during the early phase were faster and more dynamic, and they were related to sharp fluctuations in the pollutants concentration. In parallel, the processes during the late phase were slower and with a clear trend of COD decrease and protein hydrolysis. Risk analysis and risk evaluation were required in order to answer the question: "Acceptable is the risk or no?".

\subsection{Risk Analysis and Risk Evaluation}

Risk Analysis was based on determination of effect of the organic pollutants in lake sediments on the activity of the key enzymes. The risk effect $\left(E_{R}\right)$, calculated as a ratio of the enzyme activity for the risk situation to the enzyme activity for the control was showed in Table 1 . The values above 1.0 for $E_{R}$ indicated stimulation effect of the organic pollutants. The $\mathrm{E}_{\mathrm{R}}$ was 2.23 for the anDHA during the early phase and 3.03 during the late phase.

Table 1. Risk effect $\left(E_{R}\right)$ on the key enzyme activities for the early and the late phase of the simulated process.

\begin{tabular}{cccrr}
\hline Process Phase & anDHA & PAI & PRT & GAL \\
\hline early ( 0 - 46 hour) & 2.23 & 1.11 & 1.85 & 6.93 \\
late (46 - 190 hour) & 3.03 & 1.78 & 6.78 \\
\hline
\end{tabular}


This enzyme activity is indicator for the total metabolic activity of the community to mineralize the organic pollutants under anaerobic conditions. Probably, the stimulated effect of the pollutants during the early phase was corresponded to biodegradation of metabolites produced after lactose hydrolysis. The high value of $E_{R}$ on the GAL (20.93) during the early phase was a confirmation for that.

The value of $E_{R}$ for the anDHA during the late phase was higher in comparison with the early phase. The spontaneous creation of anoxic and anaerobic conditions as a consequence of the oxygen depletion during biodegradation processes was one of the reasons. The increased rate of the protein hydrolysis and mineralization of their metabolites during the late phase was another reason. The high value of $E_{R}$ on the PRT (6.78) during the late phase in comparison to the early phase (1.85) was a confirmation. The values of $E_{R}$ for the PAI for both phases were similar although the value for the late phase was higher. The PAI is indicator for heterotrophic activity of the community to degrade biodegradable organics [17], including and proteins as shown by the obtained data.

The obtained data from the risk analysis showed that the high organics concentrations led to repeatedly increase of the enzyme activities which are included in biotransformation of the specific pollutants. The $E_{R}$ on the GAL during the early phase had more visible stimulation in comparison with the late phase. It was related to the lactose biodegradation. The $\mathrm{E}_{\mathrm{R}}$ on the anDHA, PRT and PAI was higher at the late phase. That was corresponded to the protein biodegradation.

The Risk Evaluation was based on comparison of data for pollutants concentration at the end of the process for both situations (Figure 6). Only the lactose concentration for the risk event was lower in comparison with the control situation. The rapid and complete lactose utilization showed that the environmental hazard in terms of the carbohydrate component was acceptable. The COD value for the risk situation was similar to that for the control which implies that the risk of the organic pollution for environment was acceptable. The protein concentration for the risk event was 1.5 fold higher and probably there is a hazard. The added difficult degradable whey proteins and their slower biodegradation rate were the probable reasons. Furthermore, as discussed earlier the concentration of the proteins in the system depended both on the rate of biodegradation process, and the processes of restructuring of the autochthonic community. The last mention had a negative effect on the concentration of this pollutant.

The possible consequences from the above mentioned hazard in the real ecosystem were: protein precipitation and reduced physical aeration; the increase of ammonium concentrations (as a result from ammonification) could be lead to increase of the nitrate concentrations (priority pollutant according to Water Framework Directive) under aerobic conditions [21]; the toxic ammonia at $\mathrm{pH}$ above 9.2 dominates instead ammonium ions. The development of a system for early warning was required as well as proper indicators for control were necessary.

\subsection{Selection of Indicator for Early Diagnostics of Protein Pollutants in Lake Sediments}

Every selected indicator should be corresponded to some important requirements: to give accurate information about the specific environmental situation; the correlation between it and the other indicators can be described mathematically with high correlation coefficient and with a high degree of reliability; to be express indicator and

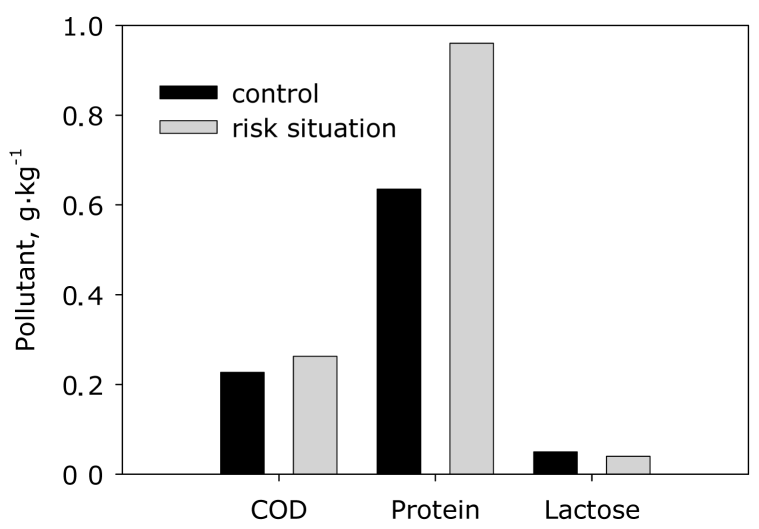

Figure 6. Concentration of the key pollutants at end of the process for the control and the risk situation. 
can be subjected to automated reading; the obtained results to be with high repeatability; it analyze does not require expensive equipment and it to be relatively cheap.

The linear correlations between the decrease of the pollutants concentrations and the increase of the enzyme activities were analyzed in order of initial selection of proper indicator for organic pollution (Table 2). A high correlation between the increase of the GAL and the decrease of the lactose concentration was ascertained for the control situation $(r=0.984)$. The increase of the enzyme activity is in direct relationship to lactose utilization and it depletion. However the lactose was not priority pollutant because it was rapidly and completely utilized from the autochthonic community.

A proportional dependence with high correlation between the increase of the PRT and the decrease of the protein concentration $(\mathrm{r}=0.951)$ as well as between the increase of the PAI and the decrease of the protein concentration $(r=0.953)$ was ascertained. Only the correlation between the increase of the PAI and the decrease of the protein concentration was remained relatively high for the risk event $(r=0.609)$. The PAI as a proper indicator for the decrease of the target pollutant (proteins) was selected therefore. Moreover, the selected indicator for the risk event correlated also with another important parameter, the decrease of the organic matter measured as $\operatorname{COD}(r=0.693)$.

The correlation between the increases of the key enzyme activities was studied and the obtained data was presented in Table 3. The increase of the PAI at organic pollution as an indicator for the increase of the anDHA $(r=0.895)$ and the PRT $(r=0.979)$ could be use during risk situation with high organic pollution. The obtained results enable the PAI to be proposed as an indicator for early warning of the organic pollution with protein nature. Moreover, only the PAI could be analyzing instead the three enzymological indicators (PAI, anDHA and PRT).

The advantages of the selected indicator were: it was express indicator (information was received for 2 hours); it can be subjected to automated reading because a colorimetric method was used for it analysis. PAI as an indicator responds to all above described requirements to the reliable and applicable indicator. Despite the promising results so far, future research should be directed to verification of this indicator in real conditions with in situ data.

This investigation discovers important details about the application of new methodology for risk assessment at pollution with high proteins concentration and of new biological indicator for this kind of pollution especially for sediments.

\section{Conclusions}

The obtained data bring to the following conclusions:

1) The autochthonic heterotrophic community responded with significantly increase of the enzyme activities during the simulated risk event in comparison with the control situation.

2) The data from Risk Assessment showed that there was a hazard from higher proteins concentration at the end of the process in comparison with the control situation. The risk about COD and lactose concentration during the risk modelling was acceptable.

Table 2. Pearson correlation coefficients (r) between the increase of enzyme activities and the decrease of pollutants concentrations for both studied situations $(P<0.05)$.

\begin{tabular}{ccccccc}
\hline \multirow{2}{*}{ Investigated Situation } & \multicolumn{5}{c}{ Pearson Correlation Coefficients between: } \\
\cline { 2 - 7 } & anDHA/COD & PAI/COD & PAI/Protein & PRT/ Protein & anDHA/Lactose & GAL/Lactose \\
\hline control situation & 0.197 & 0.017 & 0.953 & 0.951 & -0.632 & 0.984 \\
risk situation & 0.421 & 0.693 & 0.609 & 0.448 & 0.452 & 0.570 \\
\hline
\end{tabular}

Table 3. Pearson correlation coefficients between the increases of enzyme activities for both studied situations $(P<0.05)$.

\begin{tabular}{|c|c|c|c|c|c|c|}
\hline \multirow{2}{*}{ Investigated Situation } & \multicolumn{6}{|c|}{ Pearson Correlation Coefficients between: } \\
\hline & $\mathrm{PAI} / \mathrm{PRT}$ & $\mathrm{PAI} / \mathrm{anDHA}$ & PAI/GAL & PRT/anDHA & PRT/GAL & anDHA/GAL \\
\hline control situation & 0.828 & -0.492 & 0.411 & -0.074 & -0.167 & -0.732 \\
\hline risk situation & 0.979 & 0.895 & -0.166 & 0.921 & -0.156 & -0.224 \\
\hline
\end{tabular}


3) The observed correlations showed that phosphatase activity index could be used as a tool for early warning in similar risk events. However a verification of this indicator in real conditions with in situ data should be implemented.

Risk assessment, the introduction of early warning systems for hazardous events and the risk minimization through the development of alternative solutions can be tested by risk modelling. All of them aimed risk prevention, but all of them needed developing specific indicators for control. This revealed new challenges in the field of Environmental biotechnology, because “the opportunity is a risk, and the risk is an opportunity”.

\section{Acknowledgements}

This work was financially supported by the Bulgarian Ministry of Education and Science with Project DMU0356: "Innovative ecological approaches for dairy wastewater treatment” as well as by Master Degree Program “Environmental Biotechnology” in Faculty of Biology, Sofia University “St. Kliment Ohridski”.

\section{References}

[1] Todorova, Y., Lincheva, S. and Topalova, Y. (2014) Risk Management Scenario for Multiple Heavy Metal Contamination at River Sediments in the Middle Iskar Cascade. Bulgarian Journal of Agricultural Science, 20, 100-104.

[2] Bulgarian Ministry of Environment and Water (2010) Danube River Basin Management Plan. http://www.bd-dunav.org/content/upravlenie-na-vodite/plan-za-upravlenie-na-rechniia-baseyn/purb-2010-2015-v-duna vski-rayon-/

[3] Bitton, G. (2005) Wastewater Microbiology. 3rd Edition, John Wiley \& Sons, Inc., Hoboken. http://dx.doi.org/10.1002/0471717967

[4] Danalewich, J.R., Papagiannis, T.G., Belyea, R.L., Tumbleson, M.E. and Raskin, L. (1998) Characterization of Dairy Waste Streams, Current Treatment Practices, and Potential for Biological Nutrient Removal. Water Research, 32, 3555-3568. http://dx.doi.org/10.1016/S0043-1354(98)00160-2

[5] Morris, A. (2004) ISO 14000 Environmental Management Standards: Engineering and Financial Aspects. 1st Edition, John Wiley \& Sons Ltd., Chichester.

[6] Ganoulis, J. (2009) Risk Analysis of Water Pollution. 2nd Edition, Wiley-VCH Verlag GmbH \& Co. KGaA, Weinheim. http://dx.doi.org/10.1002/9783527626663

[7] Lincheva, S., Todorova, Y. and Topalova, Y. (2014) Long-Term Assessment of Self-Purification Potential of Technologically Managed Ecosystem: The Middle Iskar Cascade. Biotechnology and Biotechnological Equipment, 28, 455462. http://dx.doi.org/10.1080/13102818.2014.923623

[8] Topalova, Y. (2009) Biological Control and Management of Wastewater Treatment. PublishScieSet-Eco, Sofia.

[9] Bobba, A.G., Singh, V.P. and Bengtsson, L. (2000) Application of Environmental Models to Different Hydrological Systems. Ecological Modelling, 125, 15-49. http://dx.doi.org/10.1016/S0304-3800(99)00175-1

[10] Bredeweg, B., Salles, P., Bouwer, A., Liem, J., Nuttle, T., Cioaca, E., Nakova, E., Noble, R., Caldas, A.L.R., Uzunov, Y., Varadinova, E. and Zitek, A. (2008) Towards a Structured Approach to Building Qualitative Reasoning Models and Simulations. Ecological Informatics, 3, 1-12. http://dx.doi.org/10.1016/j.ecoinf.2007.02.002

[11] Liu, H., Li, L., Yin, C. and Shan, B. (2008) Fraction Distribution and Risk Assessment of Heavy Metals in Sediments of Moshui Lake. Journal of Environmental Science, 20, 390-397. http://dx.doi.org/10.1016/S1001-0742(08)62069-0

[12] Yang, J., Chen, L., Liu, L.Z., Shi, W.L. and Meng, X.-Z. (2014) Comprehensive Risk Assessment of Heavy Metals in Lake Sediment from Public Parks in Shanghai. Ecotoxicology and Environmental Safety, 102, 129-135. http://dx.doi.org/10.1016/j.ecoenv.2014.01.010

[13] Das, B., Nordin, R. and Mazumder, A. (2008) An Alternative Approach to Reconstructing Organic Matter Accumulation with Contrasting Watershed Disturbance Histories from Lake Sediments. Environmental Pollution, 155, 117-124. http://dx.doi.org/10.1016/j.envpol.2007.10.031

[14] Rice, E.W., Baird, R.B., Eaton, A.D. and Clesceri, L.S. (2012) Standard Methods for the Examination of Water and Wastewaters. 22nd Edition, American Public Health Association, Washington DC.

[15] Kochetov, G. A. (1980) Manual on Enzymology. High School, Moscow.

[16] Miller, G.L. (1959) Use of Dinitrosalicylic Acid Reagent for Determination of Reducing Sugar. Analytical Chemistry, 31, 426-428. http://dx.doi.org/10.1021/ac60147a030

[17] Matavulj, M., Bokorov, M., Gajin, S., Gantar, M., Stojilković, S. and Flint, K.P. (1990) Phosphatase Activity of Water as a Monitoring Parameter. Water Science and Technology, 22, 63-68. 
[18] Ladd, J.N. and Butler, J.H.A. (1972) Short-Term Assay of Soil Proteolytic Enzyme Activities Using Proteins and Dipeptide Derivates as Substrates. Soil Biology and Biochemistry, 4, 19-39. http://dx.doi.org/10.1016/0038-0717(72)90038-7

[19] Trevors, J., Mayfield, C. and Inniss, W. (1982) Measurement of Electron Transport System (ETS) Activity in Soil. Microbial Ecology, 8, 163-168. http://dx.doi.org/10.1007/BF02010449

[20] Miller, J. (1972) Experiments in Molecular Genetics. Cold Spring Harbor Laboratory, New York, 352-355.

[21] EC Directive (2000) Directive 2000/60/EC of the European Parliament and of the Council of 23 October 2000 Establishing a Framework for Community Action in the Field of Water Policy. Official Journal of the European Communities, L327, 1-72. 